PRZEGLĄD NAUK HISTORYCZNYCH 2017, R. XVI, NR 2

http://dx.doi.org/10.18778/1644-857X.16.02.12

ILONA FLORCZAK

UNIWERSYTET ŁÓDZKI*

\title{
Listy Zygmunta Celichowskiego do Kazimierza Bartoszewicza
}

W

Archiwum rodziny Bartoszewiczów, przechowywanym w Archiwum Państwowym w Łodzi, pośród obszernej korespondencji Kazimierza Bartoszewicza (1852-1930) znajdują się listy Zygmunta Celichowskiego (1845-1923), historyka, wydawcy i bibliotekarza, zwiazanego z Biblioteką Kórnicką od końca lat sześćdziesiatych XIX w. W 1869 r. młody Celichowski został sekretarzem Jana Kantego Działyńskiego ${ }^{1}$, a rok później właściciel Kórnika powierzył mu kierowanie tamtejsza biblioteka, natomiast w 1876 r. także administrowanie dobrami kórnickimi. Takie same pełnomocnictwa otrzymał w 1880 r. od kolejnego właściciela dóbr, siostrzeńca Jana, Władysława Zamoyskiego. Z Biblioteką Kórnicka Celichowski pozostał zwiazany do końca życia. W ciagu wieloletniej działalności na tym polu przyczynił się do powiększenia zbiorów, ich uporządkowania i opracowania. Staraniem bibliotekarza wiele $\mathrm{z}$ zebranych materiałów zostało wydanych drukiem ${ }^{2}$. $Z$ racji swej

* Wydział Filozoficzno-Historyczny, Instytut Historii, Katedra Historii Historiografii i Nauk Pomocniczych Historii, e-mail: ilona_florczak@wp.pl.

${ }^{1}$ Jan Kanty Działyński (1829-1880), syn Adama Tytusa i Gryzeldy z Zamoyskich, ostatni $z$ rodu właściciel dóbr kórnickich, kontynuował dzieło ojca, znacznie rozbudowując bibliotekę w Kórniku. W pamięci narodu zapisał się przede wszystkim jako mecenas kultury. Zmarł bezdzietnie, a majątek i Bibliotekę Kórnicka zapisał synowi siostry, Władysławowi Zamoyskiemu. Życie i dzieło Jana Działyńskiego przedstawił Andrzej Mężyński. Por. A. Mężyński, Jan Działyński 1829 1880, Wrocław et al. 1987.

2 Biografowie Zygmunta Celichowskiego podkreślają, że staraniem bibliotekarza kontynuowano m.in. wydawanie serii „Acta Tomiciana”. W 1996 r. ukazał się 
działalności naukowej i wydawniczej Celichowski, jako dyrektor jednej z największych bibliotek na ziemiach polskich, utrzymywał liczne kontakty korespondencyjne $z$ przedstawicielami polskiego środowiska naukowego we wszystkich trzech zaborach ${ }^{3}$. Należał do Poznańskiego Towarzystwa Przyjaciół Nauk i Akademii Umiejętności w Krakowie (od 1903 r.), był także członkiem korespondentem Towarzystwa Historyczno-Literackiego w Paryżu4. Obok działalności na rzecz biblioteki i dóbr kórnickich Celichowski poświęcił się też aktywności społecznej. Był współzałożycielem i członkiem Towarzystwa Czytelni Ludowych, Polskiego Banku Handlowego czy Towarzystwa Szerzenia Wstrzemięźliwości. Pod koniec życia, w uznaniu za zasługi, Uniwersytet Poznański nadał mu tytuł honorowego profesora historii ${ }^{5}$.

Kazimierz Bartoszewicz (1852-1930) - dziennikarz, księgarz, wydawca i działacz społeczny - urodził się w Warszawie. Był synem znanego historyka doby międzypowstaniowej Juliana (1821-1870). Większość życia spędził w Krakowie, dokąd wyjechał w 1870 r., aby rozpocząc studia na Uniwersytecie Jagiellońskim. Od tego momentu na stałe związał się $z$ tamtejszym środowiskiem literatów i dziennikarzy, stopniowo stajac się jednym $z$ najbardziej znanych redaktorów i twórców zarówno w Galicji, jak i w pozostałych zaborach. Jego felietony, eseje czy artykuły, w sposób niezwykle trafny komentujące bieżące wydarzenia, cieszyły się popularnością wśród czytelników, podobnie jak publikowane rozprawy o tematyce historycznej. Bartoszewicz słynął nie tylko $z$ sarkastycznego i jednocześnie dowcipnego stylu pisania, lecz także $z$ wzorcowej polszczyzny. Wspó1pracował $z$ wieloma periodykami i dziennikami zarówno w Galicji, jak i w innych zaborach. Niezwykle aktywny na polu działalności społecznej dążył też do konsolidacji środowiska literatów polskich.

24 zeszyt „Pamiętnika Biblioteki Kórnickiej”, w którym obszerniej przedstawiono sylwetkę Z. Celichowskiego jako bibliotekarza, wydawcę i księgarza (prowadzącego w Poznaniu kupiona od spadkobierców księgarnię Jana Konstantego Żupańskiego).

${ }^{3}$ Dla przykładu: Karol Estreicher czy Aleksander Kraushar. W 2011 r. ukazały się drukiem listy kórnickiego bibliotekarza do Alfonsa Parczewskiego. Por. E. And rysiak, Listy Zygmunta Celichowskiego do Alfonsa Parczewskiego, „Biblioteka” 2011, nr 15 (24), s. 269-270.

${ }^{4}$ E. Musierowicz, Celichowski Zygmunt, [w:] Słownik pracowników ksiązki polskiej, Warszawa-Łódź 1972, s. 105-106; „Rocznik Akademii Umiejętności w Krakowie", R. 1904/1905, Kraków 1905, s. 39.

${ }^{5}$ E. Andrysiak, op. cit. s. 270. 
Był jednym z działaczy Koła Artystyczno-Literackiego, stowarzyszenia skupiajacego literatów i artystów, głównie krakowskich, czy też nieco późniejszego Związku Literackiego (1891-1899), którego w latach 1896-1899 był prezesem. Warto nadmienić, że inicjował powstanie pism literackich i je samodzielnie redagował, m.in. „Szkice Społeczne i Literackie” (1875-1876), „Przegląd Literacki i Artystyczny” (1882-1885) czy „Przegląd Literacki” (1896-1899) Niestety, wszystkie wymienione tytuły, głównie $z$ powodów finansowych, nie zdołały utrzymać się na rynku prasowym, mimo że wśród współpracowników tych czasopism znaleźli się wybitni ludzie pióra owych czasów, a pisma były wysoko oceniane przez znawców literatury. Wysoki poziom artystyczny periodyków wpływał także na grono odbiorców - szersze warstwy społeczne nie były gotowe na tego rodzaju treści, natomiast zainteresowani nimi ludzie pióra najczęściej nie mogli sobie pozwolić na prenumeratę, przede wszystkim ze względu na niepewny byt literata w końcu XIX i poczatkach XX w. Ponadto opozycyjne wobec konserwatystów krakowskich oblicze pism również nie przysparzało wydawnictwom czytelników ${ }^{7}$.

Można przypuszczać, że korespondenci znali się osobiście. Być może spotkali się podczas obrad II zjazdu literatów i dziennikarzy, odbywającego się w dniach 19-21 lipca 1894 r. i będącego jednym z wydarzeń towarzyszących Powszechnej Wystawie Krajowej we Lwowie. Obaj korespondenci brali w tym spotkaniu czynny udział. Na przygotowany $z$ dużym rozmachem zjazd zaproszeni zostali literaci, dziennikarze, uczeni i ludzie pióra ze wszystkich trzech zaborów, a także goście innych narodowości, związani $z$ galicyjskim środowiskiem literackim, wśród nich m.in. Iwan Franko, Jarosław Vrehlicky i Edward Jelinek ${ }^{8}$.

Pierwszy $z$ listów zachowanych $\mathrm{w}$ archiwum rodziny Bartoszewiczów dotyczył spraw naukowych - był odpowiedzia bibliotekarza kórnickiego na prośbę krakowskiego literata o użyczenie materiałów

${ }^{6}$ I. Florczak, W obronie praw narodowych $-z$ działalności organizacyjnej i publicystycznej Kazimierza Bartoszewicza w Krakowie w poczatkach XX wieku, [w:] Druga Rzeczpospolita i nie tylko. Ludzie, środowiska, idee. Profesorowi Pawłowi Samusiowi w 70 rocznicę urodzin, red. J. Pietrzak, Łódź 2016, s. 29.

7 Szerzej: A. Zyga, Krakowskie czasopisma literackie drugiej połowy XIX wieku (1860-1895), Kraków-Wrocław 1983, s. 101 i n.

${ }^{8}$ Wystawa Krajowa, "Gazeta Lwowska”, nr 166, 22 VII 1894, s. 4-5; Zjazd literatów i dziennikarzy polskich, „Myśl. Dwutygodnik literacko-społeczny”, 19 (zamiast 15) VII 1894, s. 11. 
dotyczących Ignacego Działyńskiego9. Prawdopodobne wydaje się, że Bartoszewicz poszukiwał tych informacji $\mathrm{w}$ związku $\mathrm{z}$ przygotowaniem monografii dotyczacej powstania kościuszkowskiego. Publikacja ta nie była tylko opisem wydarzeń $z$ okresu insurekcji, lecz także ukazywała szerokie tło historyczne epoki ${ }^{10}$. W dwóch kolejnych listach, z lipca i sierpnia 1908 r., Zygmunt Celichowski odniósł się do kwestii stosunków polsko-ukraińskich. Temat wzajemnych relacji dwóch narodowości, koegzystujących w Galicji (szczególnie jej wschodniej części), zagościł na scenie politycznej i w debacie społecznej ze zdwojona siła w kwietniu 1908 r., po zabójstwie namiestnika Galicji Andrzeja hr. Potockiego przez ukraińskiego studenta Myrosława Siczyńskiego ${ }^{11}$. Skutkiem zamachu (dokonanego $z$ pobudek nacjonalistycznych) było zaostrzenie stosunków między przedstawicielami obu narodów, a także wzmożenie wrogich działań organizacji narodowych, zarówno polskich, jak i ukraińskich. Próbę nakreślenia obrazu wzajemnych relacji podjął też Kazimierz Bartoszewicz w nowo utworzonym (czerwiec 1908 r.) piśmie pt. „Straż Polska” - miesięczniku, który był organem prasowym organizacji o tej samej nazwie, powołanej w Krakowie w imie „obrony interesów narodu polskiego". Na marginesie warto wspomnieć, że jednym $z$ powodów powstania „Straży Polskiej” był sprzeciw wobec germanizacyjnej polityki władz wobec Polaków w zaborze pruskim $^{12}$. Przy okazji przeglądu literackiego i recenzji publikacji zbioru dokumentów Bartoszewicz dokonal swoistego podsumowania stosunków polsko-ukraińskich. Rozwiązanie konfliktów na tle narodowym widział $\mathrm{w}$ przyznaniu większych swobód narodowych mniejszościom zamieszkującym Galicję, ale też w szeroko zakrojonej

${ }^{9}$ Ignacy Józef Franciszek Adam Działyński (1754-1797) - syn Augustyna, wojewody kaliskiego, i Anny Radomickiej; rotmistrz kawalerii, od 1790 r. poseł na Sejm Czteroletni, zwolennik Konstytucji 3 maja, uczestnik wojny polsko-rosyjskiej 1792 r. W 1784 r. ożenił się z kasztelanką bełską Szczesną Woroniczówna, dziedziczką ziem na Wołyniu w okolicach Żytomierza, dokąd przeniósł się po ślubie. Ignacy Działyński z małżeństwa $z$ Woroniczówną pozostawił syna Zygmunta i dwie córki. S. Kieniewicz, Działyński Ignacy Józef Franciszek Adam (1754-1797), [w:] Polski słownik biograficzny, t. VI, Kraków 1946, s. 80.

${ }_{10}$ K. Bartos zewi cz, Dzieje insurekcji kościuszkowskiej, wyd. 1, Wiedeń 1909.

${ }^{11}$ O zabójstwie hr. Andrzeja Potockiego i jego skutkach por. C. Partacz, Od Badeniego do Potockiego. Stosunki polsko-ukrainskie w Galicji w latach 18881908, Toruń 1997, s. 227-232.

12 Szerzej o utworzeniu „Straży Polskiej”: I. Florczak, op. cit., s. 32-34. 
akcji edukacyjnej skierowanej do ludu, którego świadomość należało kształtować w duchu polskim. Podobne stanowisko reprezentował, mieszkający w Kórniku, czyli w znacznym oddaleniu od miejsca konfliktów, Zygmunt Celichowski. Był żywo zainteresowany kwestiami oświaty dla ludu, także w Galicji. Warto przypomnieć, że podczas lwowskiego wspomnianego zjazdu literatów i dziennikarzy był przewodniczaccym sekcji II („dla oświaty ludowej”), w czasie której dyskutowano o potrzebie tworzenia czytelni ludowych na prowincji czy kolportowania dzieł z kanonu literatury narodowej. Dla bibliotekarza $z$ Kórnika poruszenie kwestii ukraińskiej w prasie galicyjskiej było inspiracją do przedstawienia własnego punktu widzenia antagonizmów między narodami. Jego poglądy i proponowane w liście rozwiązania były przemyśleniami człowieka bezpośrednio niezaangażowanego w konflikt, patrzącego $z$ pewnego oddalenia na sprawy galicyjskie. Być może i $z$ tego powodu Bartoszewicz uznał, że głos uczonego i działacza $z$ Wielkopolski był na tyle ważny, że powinien zostać upubliczniony. List, datowany na 11 lipca 1908 r., został, za zgoda jego autora, opublikowany we fragmentach na łamach „Straży Polskiej” w rubryce Głosy członków i czytelników ${ }^{13}$.

Publikowane listy sa przechowywane, jak wspomniano, w archiwum łódzkim, w zespole Archiwum rodziny Bartoszewiczów. Stanowią zaledwie ułamek korespondencji do Kazimierza Bartoszewicza zgromadzonej w wyniku działalności zawodowej. Podczas opracowania listów uwspółcześniono ortografię i interpunkcję, zgodnie $z$ obowiązujaccymi regułami. W celu oddania stylu epoki niektóre $\mathrm{z}$ wyrazów pozostawiono $\mathrm{w}$ niezmienionej formie gramatycznej. Wszelkie uzupełnienia i braki w tekście oraz nieodczytane fragmenty zaznaczono w nawiasie kwadratowym. W odwołaniach umieszczono niezbędne wyjaśnienia dotyczące osób i zagadnień wymagających komentarza.

$$
* * *
$$

${ }^{13}$ Głosy członków i czytelników „Straży Polskiej”, „Straż Polska”, nr 4 z sierpnia 1908, s. 5. 
1.

\section{Od Zygmunta Celichowskiego}

Kórnik, 9 lutego 1908 [r.]

\section{Łaskawy Panie!}

Pragnąłbym najchętniej przysłużyć się Panu materiałami do życiorysu Ignacego Działyńskiego ${ }^{1}$, ale bodaj to będzie w mojej mocy. Winienem dla objaśnienia nadmienić, że starego archiwum Działyńskich Kórnik nie posiada. W dawnych czasach Kórnik nie był siedziba rodziny Działyńskich - w wieku XVIII wyszedł on nawet przez ożenek $z$ rąk Działyńskich, a był przez 2 generacje w rękach Szołdrskich ${ }^{2}$.

Dopiero Xawery ${ }^{3}$ i Ignacy wydobyli go $z$ rak Szołdrskich na początku XIX wieku. Ale Xawery miał siedzibę w Konarzewie, Ignacy zaś pozostał w zaborze moskiewskim ${ }^{4}$. Dopiero Tytus Dz.[iałyński] ${ }^{5}$ przeniósł swą siedzibę do Kórnika między r. 1820 a 1830 - a na dobre osiadł w nim dopiero w r. 1840, po powrocie $z$ Galicji. Działyńscy odebrali od Szołdrskich Kórnik jako arabiam desertam - puste, zniszczone i podmokłe mury. Co dzisiaj ma Kórnik, to zebrali hr. Tytus i hr. Jan ${ }^{6}$.

[1] ${ }^{1}$ Ignacy Działyński (1754-1797); por. przyp. 9 z części wstępnej.

${ }^{2}$ W 1790 r., po śmierci Teofili z Działyńskich 1.v. Szołdrskiej, 2.v. Potulickiej, dobra odziedziczył jej syn Feliks Szołdrski, a po jego bezpotomnej śmierci przeszły w posiadanie brata stryjecznego Wiktora Szołdrskiego. W 1801 r., w wyniku wygranego procesu sadowego, dobra powróciły w posiadanie rodziny Działyńskich.

${ }^{3}$ Ksawery Szymon Tadeusz Działyński (1756-1819) - syn Augustyna, wojewody kaliskiego, i Anny Radomickiej, młodszy brat Ignacego; poseł na Sejm Czteroletni z ziemi wschowskiej, zwolennik Konstytucji 3 maja i jeden $z$ jej współtwórców; senator-wojewoda Księstwa Warszawskiego i Królestwa Polskiego; ożeniony z Justyną Dzieduszycka miał syna Tytusa i córki Paulinę Dzieduszycką i Klaudynę Potocką. Zmarł w Konarzewie, gdzie gospodarował.

${ }^{4}$ Ignacy Działyński zmarł w 1797 r. na Wołyniu. Być może z młodszym bratem procesował się z Szołdrskimi o dobra kórnickie, jednak końca sprawy sądowej nie dożył.

5 Adam Tytus Działyński (1796-1861) - syn Ksawerego i Justyny z Dzieduszyckich, polski arystokrata i polityk, zasłużony w dziejach Poznania, twórca zbiorów kórnickich, mecenas sztuki, bibliofil i wydawca źródeł historycznych.

${ }^{6}$ Por. przyp. 1 z części wstępnej. 
Syn Ignacego - Zygmunt ${ }^{7}$, a następnie wnuk Bronisław ${ }^{8}$ przenieśli się na południe Polski, na Ukrainę. Z Kórnikiem prawie żadnej nie mieli styczności - toteż nie mamy żadnych do życiorysu Ignacego materiałów, nie mamy nawet korespondencji. Skoro będzie można $\mathrm{w}$ nieopalonych pokojach bibliotecznych pracować, przewertuje jeszcze raz papiery, gdzie bym się mógł spodziewać jakich szczegółów o Ignacym - jeżeli co znajdę, chętnie tym Panu służyć będę.

Dla mnie [wyraz nieczytelny] postać Ignacego - wielki krok i byłbym szczęśliwy, gdybym mógł choć jedna cegiełkę przyłożyć do pomnika, który mu Pan chcesz w swej pracy wystawić. Postać jego zewnętrzna jest już bardzo ujmująca. Posiadam fotografię ze współczesnego jego portretu. Gdybyś Pan pragnął zrobić $z$ niej reprodukcję, chętnie nią służyć będę. Dał mi $z$ niej odbitkę p. Kraushar ${ }^{9}$, ale nieosobliwie się udała.

W archiwum majątkowym mam sporo akt tyczących się także Ignacego, gdyż przez czas pewien wszystkie prawne czynności załatwiali razem obaj bracia. Zobaczę, czy tam nie znajdę szczegółów o jego śmierci. Mamy też w Kórniku obraz przedstawiający zaręczyny Ignacego $z$ Woroniczówną. Gdybyśs sobie Pan życzył pomieścić w swej pracy reprodukcję tego obrazu, kazałbym $z$ niego zrobić fotografię.

Nie wiem, na kiedy Panu potrzebne materiały wszelkie odnoszące się do Ignacego Działyńskiego. Muszę się wystrzegać przeziębienia, [i silny kaszel?], który radzi ostrożność w przebywaniu w niepalonych, a nie tylko w zimnych, ale jak zwykle w bibliotekach, nie bardzo zdrowych miejscach. Jeżeli więc nie ma gwałtu, to proszę o termin dylacyjny ${ }^{10}$, abym już z cała swobodą mógł przewertować wszystko, co by mogło zawierać pożądane dla Pana szczegóły.

7 Zygmunt Działyński (1791-1850) - dziedzic Rzyszczewa i Trojanowa na Ukrainie, ożeniony z Aniela, a po jej śmierci z Emilia, córkami Stanisława Wodzickiego, prezesa senatu Wolnego Miasta Krakowa.

8 Bronisław Działyński (1823-1860) - syn Zygmunta i Anieli z Wodzickich, ostatni właściciel Rzyszczewa, Trojanowa, Raby i Denisza na Ukrainie. Ostatni męski potomek ukraińskiej linii Działyńskich.

${ }_{9}$ Aleksander Kraushar (1843-1931) - warszawski historyk, adwokat, publicysta i poeta. Miał szerokie kontakty $z$ przedstawicielami środowiska literackiego we wszystkich trzech zaborach. Na przełomie wieku XIX i XX prowadził w Warszawie salon, gdzie skupiało się życie kulturalne miasta. Był członkiem założycielem Towarzystwa Naukowego Warszawskiego i członkiem Towarzystwa Miłośników Historii (i jego prezesem w latach 1912-1931).

10 Dylacyjny - odroczony. 
Pozwalam sobie zwrócić uwagę Pańską na kierunek, w którym by może opłaciły się poszukiwania materiałów odnoszących się do życiorysu Ignacego. Otóż żoną ostatniego $z$ tej gałęzi Działyńskich, która szła od Ignacego, Bronisława Działyńskiego, była Komorowska $z$ domu. Pozostały $z$ tego małżeństwa córki, $z$ których jedna wyszła za Stadnickiego ${ }^{11}$. Może w tym domu znalazłyby się materiały do życiorysu Ignacego Dz.[iałyńskiego].

Żałuję, że na razie nie mogę się Panu niczym przysłużyć, ale nie tracę nadziei, będę szukał, a może się co znajdzie.

\section{Załączam wyrazy szczerego szacunku powolny sługa \\ Dr Celichowski}

Autograf, sygn. 2946, k. 7-10.

\section{2.}

\section{Od Zygmunta Celichowskiego}

Kórnik, 11 lipca 1908 [r.]

\section{Łaskawy Panie!}

W numerze $3^{\text {im }}$ „Straży Polskiej” ${ }^{1}$ wyczytałem wiadomość o zamiarze wydawania w języku ruskim dziełek i broszur dla zruszczonego [!] ludu polskiego we wschodniej Galicji.

Zastanawiałem się nieraz nad tą sprawą i uważałem zawsze za rzecz pożyteczna rozszerzanie między ludem ruskim takich uczciwych wydawnictw, które by zamiast nienawiści rasowej czy szczepowej szerzyły między Rusinami myśl zgody i wspólności [!] $z$ narodem polskim. Myśl to zreszta nienowa, bo niezawodnie była

${ }^{11}$ Córka Bronisława, Maria (ok. 1840-1894) wyszła za mąż za Władysława hr. Stadnickiego (1830-1894).

[2] ${ }^{1}$ „Straż Polska” - miesięcznik, ukazujący się w Krakowie w latach 19081914 , organ prasowy organizacji o tej samej nazwie, której celem działania miała być szeroko rozumiana obrona interesów narodowych. 
ona pobudką do wydania w r. 1879 w języku ruskim Chociszewskiego $^{2}$ Istorija Polszy, Łytwy $i$ Rusy, i to w dwóch wydaniach: alfabetem ruskim i łacińskim. Ciekawym, czy to wydanie, którego „kołownyj skład" był w księgarni Seyfartha i Czajkowskiego ${ }^{3}$, już wyczerpane. Poruszyłem myśl ponownego wydania przez paru laty - odpowiedziano mi, że byłby to trud daremny, bo nikt $z$ Rusinów nie kupiłby dziś takiej książki. Gdyby nie kupowano, należałoby darmo rozdawać. Moim zdaniem wszystkie dzieła naszej literatury powinny mieć przekład ruski. To byłaby może najskuteczniejsza propaganda zgody między nami a Rusinami. Za taka książkę, która warto by przełożyć na język ruski, uważam także powieść Jeża ${ }^{4}$ pod tytułem Hryhor serdeczny 5 . Może by się dało [rozszerzyć?] wśród Rusinów, umiejących po polsku, pewną ilość egzemplarzy tej powieści.

A czy nie należałoby też rozpoczą́ propagandy w celu zaprowadzenia u Rusinów alfabetu łacińskiego? Myśl tę należałoby może także poruszyć na praskim zjeździe słowiańskim ${ }^{6}$.

Załączam wyrazy głębokiego szacunku $Z$ uprzejmym pozdrowieniem Powolny sługa

Dr Celichowski

Autograf, sygn. 2946, k. 5-6.

2 Józef Chociszewski (1837-1914) - urodzony w zaborze pruskim polski działacz ludowy i pisarz, redaktor i wydawca, autor wielu prac z zakresu literatury i historii przeznaczonych dla ludu.

${ }^{3}$ Gustaw Seyfarth (1840?-1923) i Damian Czajkowski prowadzili księgarnię sortymentowo-nakładową we Lwowie od 1868 r. Obok wydawania i sprzedaży bardzo zróżnicowanych tematycznie publikacji mieli księgarnię i wypożyczalnię książek, nut i instrumentów muzycznych.

4 Teodor Tomasz Jeż [Zygmunt Miłkowski] (1824-1915) - powieściopisarz, działacz demokratyczny i niepodległościowy, publicysta. Tworzył utwory o tematyce słowiańskiej i południowosłowiańskiej, często, w zamaskowany sposób, wplatając w nie sprawy polskie.

${ }^{5}$ Hryhor serdeczny - powieść wydana w $1873 \mathrm{r}$.

${ }^{6}$ Zjazd neosłowiański w Pradze - kongres przedstawicieli narodów słowiańskich obradujący w dniach 12-18 VII 1908 r. Celem było zbliżenie narodów słowiańskich i ich wspólny front w walce $z$ germanizacją. 


\section{3.}

\section{Od Zygmunta Celichowskiego}

Kórnik, 17 sierpnia 1908 [r.]

\section{Wielce łaskawy Panie!}

Nie pamiętam dosłownie, co napisałem do Pana w sprawie wydawnictwa książek ruskich. Sądzę, że nie masz tam niczego, do czego bym się publicznie przyznać nie mógł i z tego względu nie miałbym obawy do podpisania się pod listem. Inna rzecz, czy list był ujęty w taką formę, by się nadawał do ogłoszenia.

My, Wielkopolanie, znamy sprawę ruska tylko $z$ daleka, bo jej się nie dotykamy. Zawsze więc jest obawa, byśmy w najlepszej wierze sprawie nie zaszkodzili. Panowie macie bezpośrednia styczność $z$ Rusinami i sprawą ruską i możecie najlepiej ocenić, co czynić trzeba. Nasza rzecza jest pomagać Panom w tym kierunku, jaki Panowie wytkniecie.

Jeżeli byś Pan jednakże sądził, że ogłoszenie listu, czy to anonimowo, czy $z$ podpisaniem nazwiska, mogłoby się na cośkolwiek przydać, chociażby do wywołania dyskusji, to zgoda na ogłoszenie.

W naszych gazetach była przed niejakim czasem wiadomość o bardzo pojednawczym wystapieniu dyrektora gimnazjum p. Sabata ${ }^{1}$. Nie mogłem się powstrzymać, by nie napisać do niego kilku słów $z$ podziękowaniem za to wystąpienie i $z$ poruszeniem myśli wydawnictwa, które by miało na celu zbliżenie się dwóch powaśnionych braci. Panowie niezawodnie znacie bliżej dyr.[ektora] Sabata, bądź co bądź chciałem zwrócić uwagę Pańską na jego osobę.

Czy Kałużniacki ${ }^{2}$ jest jeszcze profesorem uniwersytetu w Czerniowcach?

Korespondowałem $z$ nim niegdyś i miałem uczucie, że w dobrej wierze rozchwiałem jego niechęć czy uprzedzenie, jak[ie] miał do nas.

[3] ${ }^{1}$ Mikołaj Sabat - dyrektor c. k. gimnazjum w Stanisławowie z wykładowym językiem ruskim („Szematyzm” 1908).

${ }^{2}$ Emil Kałużniacki (1845-1914) - filolog słowiański, zatrudniony na uniwersytecie w Czerniowcach w 1875 r. W latach 1889-1890 rektor tejże uczelni. 
Poznałem też Frankę 3 , który w r. 1894 podczas wystawy lwowskiej na zjeździe literackim ${ }^{4}$, na którym przewodniczyłem w sekcji oświaty ludowej, pracował jeszcze razem z nami. Tempora mutantur $^{5}$, ludzie się zmieniają także, ale zmieniają się niejednokrotnie. Co Frankę spowodowało do zajęcia nienawistnego wobec nas stanowiska? Graja w tym nieraz względy osobiste. My nieraz zapominamy o naszym przysłowiu: [„]czapką, papką i solą ludzie ludzi niewolą"].

List Pański wybudził znowu dawną myśl moją, czy nie należałoby wdrożyć akcji pewnej w kierunku stworzenia, a raczej odnowienia unii polsko-ruskiej. Czy nie można by i nie należałoby założyć towarzystwa $z$ wytkniętym celem powyższym? Niechby się na początek zebrało Koło złożone z 20 Polaków i tyleż Rusinów, które by zataczało coraz szersze kręgi, a które by miałoby wypisane na swym sztandarze: wygładzenie niesnasek i unię!

Przyrzekłem przesłać Panu fotografię z portretu Ignacego Działyńskiego, znajdującego się w naszym pałacu poznańskim. Nie bardzo udana fotografia, bo obraz stary, może trochę zabrudzony. W Kórniku mamy jeszcze inny obraz, wyraźniejszy, ale jak sądzę, jest to kopia $z$ poznańskiego i dlatego $z$ tego, jako więcej autentycznego, kazałem zrobić fotografię.

Załączam wyrazy szczerego i głębokiego szacunku powolny sługa

Dr Celichowski

${ }^{3}$ Iwan Franko (1856-1916) - ukraiński poeta, pisarz, slawista, działacz społeczny i polityczny, znawca literatury polskiej, redaktor czasopism, współtwórca galicyjskich ruchów postępowych. Działał zarówno w środowisku polskim, jak i ukraińskim. Współpracował $z$ wieloma przedstawicielami polskiego środowiska literackiego. Autor listu trafnie ocenił motywy, które kierowały ukraińskim działaczem i wpłynęły na zmianę stanowiska wobec narodu polskiego - osobiste niepowodzenia, czyli przegrana w wyborach do Sejmu Krajowego Galicji i niedopuszczenie do objęcia katedry literatury i języka ukraińskiego na Uniwersytecie Lwowskim miały niewattpliwie wpływ na rozgoryczenie Franki i jego wystąpienie z krytyka dzieł Adama Mickiewicza w artykule opublikowanym w 1897 r., co $z$ kolei oburzyło Polaków.

${ }^{4}$ Por. przyp. nr 8 z części wstępnej. Iwan Franko wygłosił wówczas referat o wzajemnym stosunku literatury polskiej i ukraińskiej, postulując potrzebę bliższego zapoznania Polaków z dziełami pisarzy ukraińskich, m.in. podczas organizowanych odczytów i popularyzacji wydawnictw.

5 Tempora mutantur (sentencja łacińska) - czasy się zmieniają. 
PS W tej chwili przychodzi mi na myśl, czy w liście moim nie masz jakich ekskursji ${ }^{6}$ przeciwko rzadowi pruskiemu. To trzeba by opuścić nie [ze] względu na mnie, lecz ze względu na Kórnik.

Autograf, sygn. 2946, k. 1-3.

\section{Bibliografia}

\section{Ź́ródeA ARCHIWALNE}

Archiwum Państwowe w Łodzi

Archiwum rodziny Bartoszewiczów, sygn. 2946.

WYDAWNICTWA ŹRÓDŁOWE

Andrysiak E., Listy Zygmunta Celichowskiego do Alfonsa Parczewskiego, „Biblioteka” 2011, nr 15 (24), s. 269-279.

\section{Prasa}

„Rocznik Akademii Umiejętności w Krakowie”, R. 1904/1905, Kraków 1905.

„Straż Polska”, nr 4 z sierpnia 1908.

Wystawa Krajowa, „Gazeta Lwowska”, nr 166, 22 VII 1894 r.

Zjazd literatów i dziennikarzy polskich, „Myśl. Dwutygodnik literacko-społeczny”, 19 (zamiast 15) VII 1894.

\section{Opracowania}

Bartoszewicz K., Dzieje insurekcji kościuszkowskiej, Wiedeń 1909.

Florczak I., W obronie praw narodowych $-z$ działalności organizacyjnej $i$ publicystycznej Kazimierza Bartoszewicza w Krakowie w poczatkach XX wieku, [w:] Druga Rzeczpospolita i nie tylko. Ludzie, środowiska, idee. Profesorowi Pawłowi Samusiowi w 70 rocznice urodzin, red. J. Pietrzak, Łódź 2016, s. 25-38.

Kieniewicz S., Działyński Ignacy Józef Franciszek Adam (1754-1797), [w:] Polski słownik biograficzny, Kraków 1946, t. VI, s. 80.

Mężyński A., Jan Działyński 1829-1880, Wrocław et al. 1987.

Musierowicz E., Celichowski Zygmunt, [w:] Słownik pracowników książki polskiej, Warszawa-Łódź 1972, s. 105-106.

Partacz C., Od Badeniego do Potockiego. Stosunki polsko-ukraińskie w Galicji w latach 1888-1908, Torun 1997.

Zyga A., Krakowskie czasopisma literackie drugiej połowy XIX wieku (1860-1895), Kraków-Wrocław 1983.

\footnotetext{
${ }^{6}$ Ekskursja - wycieczka, wyprawa.
} 